\title{
FAKTOR PENYEBAB KEJADIAN STAGNANT DAN STOCKOUT DI INSTALASI FARMASI UPT RUMAH SAKIT MATA MASYARAKAT JAWA TIMUR
}

\author{
Imas Sayyidati Hadidah*, Thinni Nurul Rochmah* \\ *Fakultas Kesehatan Masyarakat, Universitas Airlangga, Surabaya \\ E-mail: sayyidatihadidah@gmail.com
}

\begin{abstract}
ABSTRAK
Logistik obat termasuk salah satu aspek penting dalam bidang kesehatan. Pembelanjaan untuk penyediaan obat membutuhkan hampir $40 \%$ dari total anggaran operasional rumah sakit. Oleh karena itu obat harus dikelola secara efektif dan efisien. Ketidak efisienan dalam melakukan manajemen logistik memberikan dampak negatif terhadap rumah sakit baik dari segi medis maupun non medis. Pengelolaan obat di Instalasi Farmasi UPT Rumah Sakit Mata Masyarakat Jawa Timur masih belum bejalan dengan baik dibuktikan dengan angka kejadian obat stagnant yang cukup tinggi yaitu sebesar 39\% dan $29 \%$ untuk kejadian stockout. Tujuan dari penelitian ini adalah menghitung kerugian akibat kejadian obat stagnant dan stockout serta melakukan analisis faktor penyebab terjadinya obat stagnant dan stockout di Instalasi Farmasi UPT Rumah Sakit Mata Masyarakat Jawa Timur tahun 2015. Penelitian ini termasuk deskriptif dengan pendekatan kuantitatif dengan menggunakan metode observasional yang dilakukan secara cross sectional dan melakukan perhitungan kerugian akibat kejadian obat stagnant dan stockout di Instalasi Farmasi UPT Rumah Sakit Mata Masyarakat Jawa Timur tahun 2015. Hasil penelitian ini untuk penyebab kejadian obat stagnant dan stockout di Instalasi Farmasi UPT RSMM Jawa Timur pengadaan obat tidak efektif sebagai akibat dari perencanan yang belum tepat, pendistribusian obat yang kurang efektif, serta kesalahan pada kegiatan pencatatan dan pelaporan. Kesimpulan yang didapatkan dari penelitian ini adalah masih belum terlaksnannya sistem manajemen logistik dengan benar sehingga menyebabkan kerugian yang cukup besar akibat adanya kejadian obat stagnant dan stockout di Instalasi Farmasi UPT RSMM Jawa Timur. Saran yang dapat diberikan yaitu dengan menerapkan metode yang sesuai pada setiap proses manajemen logistik serta mengembangkan sistem informasi yang tepat untuk mengontrol persediaan obat.
\end{abstract}

Kata Kunci : Manajemen Obat, Stagnant, Stockout, Kerugian.

\begin{abstract}
Drugs logistic, is one of the important aspects in the health field. Supply of drugs requires almost $40 \%$ of the total operating budget of the hospital. Therefore, the drugs should be managed effectively and efficiently. Inefficiency in managing the logistics cause negative impact to the hospital in terms of both medical and non-medical. Drugs mangement at the Pharmacy Installation UPT Rumah Sakit Mata Masyarakat Jawa Timur still not going well evidenced by the prevalence of drugs stagnant is quite high at $39 \%$ and $29 \%$ for the occurrence of stockout. The purpose of this study is to calculate the losses due to the incidence of drug stagnant and stockout and analyze the causes of drugs stagnant and stockout in Pharmacy Installation UPT Rumah Sakit Mata Masyarakat Jawa Timur in 2015. This study included descriptive quantitative approach using observational methode
\end{abstract}


conducted by cross sectional and calculating losses due to the incidence of drugs stagnant and stockout in Pharmacy Installation UPT Rumah Sakit Mata Masyarakat Jawa Timur in 2015. The cause of drug stagnant and stockout in Pharmacy Installation is ineffective drugs procurement as a result of less precise drugs planning, less effective drugs distribution, and errors in recording and reporting activities. The conclusions obtained from this study is logistics system management still not going properly, causing substantial losses due to the occurrence of drugs stagnant and stockout. The advices that can be given are by applying the appropriate methods on any logistics management processes and develop appropriate information systems to control drugs supply.

Key Words: Drugs Management, Stagnant, Stockout, Losses

\section{PENDAHULUAN}

Manajemen logistik merupakan seni dan ilmu yang mengatur dan mengontrol arus barang, energi, informasi, dan sumberdaya lainnya dengan tujuan untuk mengoptimalkan penggunaan modal. Dalam penyelenggaraannya terdapat beberapa hal yang perlu diperhatikan yaitu tepat waktu, tepat jumlah, tepat jenis, tepat harga, tepat kualitas.

Ketidakefisienan melakukan manajemen logistik memberikan dampak negatif terhadap rumah sakit baik dari segi medis maupun non medis. Manajemen logistik juga digunakan sebagai informasi yang digunakan dalam pengambilan kebijakan di rumah sakit.

UPT Rumah Sakit Mata Masyarakat Jawa Timur sebagai BLUD memiliki kewenangan penuh untuk mengelola biaya operasional termasuk didalamnya yaitu persediaan logistik obat. Namun dalam pelaksanaannya, manajemen persediaan logistik obat di Instalasi Farmasi UPT Rumah Sakit Mata Masyarakat masih belum maksimal. Hal tersebut dibuktikan dengan adanya kejadian obat yang mengalami stagnant memiliki rata-rata kejadian sebesar 39\%, sedangkan obat yang mengalami stockout memiliki ratarata kejadian sebesar 29\% selama tahun 2015 yang disuguhkan dalam tabel berikut:

\begin{tabular}{|c|c|c|c|c|c|c|c|c|c|c|}
\hline \multirow{2}{*}{ No } & \multirow{2}{*}{ Triwulan } & \multirow{2}{*}{$\begin{array}{c}\text { Jumlah } \\
\text { Jenis Obat }\end{array}$} & \multicolumn{2}{|c|}{ Stagnant } & \multicolumn{2}{|c|}{ Stockout } & \multicolumn{2}{|c|}{ Normal } & \multicolumn{2}{|c|}{ Jumlah } \\
\hline & & & $\mathbf{N}$ & $\%$ & $\mathbf{n}$ & $\%$ & $\mathbf{n}$ & $\%$ & $\mathbf{N}$ & $\%$ \\
\hline 1. & $\begin{array}{c}\text { Triwulan ke- } \\
1\end{array}$ & 250 & 93 & 37,2 & 96 & 38,4 & 61 & 24,4 & 250 & 100 \\
\hline 2. & $\begin{array}{c}\text { Triwulan ke- } \\
2\end{array}$ & 252 & 122 & 48,4 & 51 & 20,2 & 79 & 31,4 & 252 & 100 \\
\hline 3. & $\begin{array}{c}\text { Triwulan ke- } \\
3 \\
\end{array}$ & 263 & 117 & 44,5 & 56 & 21,3 & 90 & 34,3 & 263 & 100 \\
\hline 4. & $\begin{array}{c}\text { Triwulan ke- } \\
4\end{array}$ & 268 & 68 & 25,9 & 96 & 36,6 & 102 & 38,5 & 268 & 100 \\
\hline \multicolumn{3}{|c|}{ Rata-rata kejadian } & \multicolumn{2}{|c|}{$39 \%$} & \multicolumn{2}{|c|}{$29 \%$} & \multicolumn{2}{|c|}{$32 \%$} & \multicolumn{2}{|c|}{$100 \%$} \\
\hline
\end{tabular}

Sumber : Hasil pengolahan data laporan persediaan bahan habis pakai UPT Rumah Sakit Mata Masyarakat Jawa Timur tahun 2015

Keterangan tabel:

Stagnant : Keadaan ketika jumlah sisa persediaan obat lebih dari tiga kali jumlah pemakaian rata-rata.

Stockout : Keadaan ketika jumlah sisa persediaan kurang dari pemakaian ratarata.
Berdasarkan Tabel dapat diketahui bahwa logistik obat selama tahun 2015 mengalami kejadian stagnant dan stockout yang fluktuatif. Kejadian stagnant memiliki rata-rata kejadian sebesar 39\%. Sedangkan obat yang mengalami stockout memiliki rata-rata kejadian sebesar $29 \%$. 
Tujuan dari penelitian ini adalah untuk mengetahui faktor penyebab kejadian obat stagnant dan stockout di UPT Rumah Sakit Mata Masyarakat Jawa Timur tahun 2015. Hasil dari penelitian ini diharapkan dapat menjadi bahan masukan dan rekomendasi bagi pihak UPT Rumah Sakit Mata Masyarakat Jawa Timur untuk memperbaiki sistem manajemen logistik obat sehingga dapat mengurangi kejadian obat stagnant dan stockout yang dapat menyebabkan kerugian bagi rumah sakit.

\section{METODE}

Penelitian ini merupakan penelitian observasional, yaitu penelitian yang dilakukan tanpa memberi perlakuan terhadap objek penelitian. Berdasarkan analisis datanya, penelitian ini termasuk deskriptif dengan pendekatan kuantitatif. Hasil penelitian akan disampaikan secara naratif terhadap proses pelaksanaan manajemen obat. Jika ditinjau dari segi waktu, penelitian ini termasuk dalam penelitian cross sectional karena variabel diukur dan diamati dalam satu waktu tertentu. Penelitian ini dilakukan di Instalasi farmasi UPT Rumah Sakit Mata Masyarakat Jalan Gayung Kebonsari Timur No. 49, Ketintang, Gayungan, Jawa Timur.

Unit analisis dari penelitian ini adalah Instalasi farmasi UPT Rumah Sakit Mata Masyarakat Jawa Timur. Dengan variabel penelitian meliputi perencanaan kebutuhan, pengadaan, penyimpanan, distribusi, serta pencatatan dan pelaporan obat yang mengalami stagnant dan stockout.

\section{HASIL DAN PEMBAHASAN}

\section{Sistem Perencanaan Kebutuhan Obat}

Instalasi Farmasi UPT Rumah Sakit Mata Masyarakat Jawa Timur melakukan perencanaan kebutuhan keseluruhan setiap tahun dengan membuat formularium kebutuhan obat dengan melibatkan pihak tidak hanya petugas Instalasi Farmasi, namun juga dokter, dan pihak yang terkait seperti misalnya bagian keuangan rumah sakit. Selain itu kebutuhan obat di luar formularium terutama untuk obat, alat habis pakai (AHP), dan bahan habis pakai (BHP) tergantung pada user, dalam hal ini user yang dimaksudkan adalah dokter. Perencanaan kebutuhan obat sebelum melakukan pengajuan pengadaan dilakukan dengan melihat sisa ketersediaan obat di Instalasi Farmasi.

Kegiatan yang dilakukan dalam perencanaan diantaranya adalah penentuan jumlah kebutuhan serta waktu pemesanan obat yang dilakukan oleh ketua Instalasi Farmasi. Untuk jumlah kebutuhan obat yang akan dipesan, di Instalasi Farmasi sudah dilakukan dengan melihat kebutuhan setiap jenis obat pada periode waktu sebelumnya. Namun, selanjutnya petugas Instalasi Farmasi memperkirakan peningkatan kebutuhan obat untuk periode waktu selanjutnya yang dalam hal ini perkiraan peningkatan kebutuhan tidak ditentukan dengan metode khusus. Sedangkan perencanaan waktu untuk dilakukannya pemesanan obat berdasarkan dari hasil wawancara ditentukan dengan menggunakan metode ROP (Re-Order Point).

Berdasarkan hasil penelitian Instalasi Farmasi UPT Rumah Sakit Mata Masyarakat Jawa Timur masih belum melakukan perencanaan dengan menggunakan metode perencanaan yang dapat membantu pencapaian tujuan perencanaan obat dan perbekalan kesehatan yaitu untuk menetapkan jenis serta jumlah obat dan perbekalan kesehatan yang tepat, sesuai dengan kebutuhan pelayanan kesehatan dasar termasuk obat program kesehatan yang telah ditetapkan (Direktorat Jenderal Bina Kefarmasian dan Alat Kesehatan, 2010).

Selain itu, petugas perencanaan cenderung kurang memperhatikan jumlah persediaan item obat yang akan dilakukan pemesanan apakah jumlahnya masih mencukupi untuk pemakaian pada periode waktu selanjutnya. Namun memang hal tersebut 
tidak selamanya dapat menjadi acuan mengingat adanya ketidakpastian dalam peggunaan obat. Kurangnya kontrol terhadap persediaan obat juga disebabkan pencatatan dan pelaporan dari perbekalan farmasi masih kurang lengkap serta pencatatannya tidak dilakukan secara rutin dan kurang teliti. Hal ini dibuktikan dengan pengisian kartu stok yang terkadang lupa tidak diisi saat melakukan pengeluaran serta pencatatan pada buku laporan sering tidak diurutkan sesuai tanggal penerimaan atau pengeluaran. Selain itu pancatatan pada buku laporan dan SIMBADA hanya dilakukan jika ada waktu, tidak dilakukan secara rutin. Petugas juga masih kurang memperhatikan penggunaan obat pada beberapa periode waktu sebelumnya sehingga belum bisa melakukan forecastig terhadap jumlah persedian obat yang harus tersedia untuk mencukupi permintaan periode selanjutnya.

Berdasarkan kondisi di Instalasi Farmasi UPT Rumah Sakit Mata Masyarakat, metode yang sesuai untuk menentukan jumlah pemesanan obat pada periode waktu selanjutnya dapat menggunakan metode trend linier per tiga bulanan. Penggunan metode ini yaitu perencanaan dilakukan dengan melihat tren pemakaian obat tia bulan sebelumnya. Untuk waktu pemesanan Instalasi Farmasi hanya perlu memperbaiki dalam aplikasi metode ROP.

\section{Sistem Pengadaan Kebutuhan Obat}

Berdasarkan hasil wawancara, diketahui bahwa pengadaan di Instalasi Farmasi UPT Rumah Sakit Mata Masyarakat Jawa Timur dimulai ketika setiap unit pelayanan dan poli di memberikan permintaan kebutuhan obat kepada Instalasi Farmasi. Permintaan kebutuhan ini biasanya dilakukan pada hari Jumat. Permintaan dari setiap poli dan unit pelayanan selanjutnya dilakukan rekapitulasi permintaan. Jika permintaan tidak tersedia dalam hal ini obat mengalami kehabisan stok maka Instalasi Farmasi akan melaporkan kepada tim pengadaan.

Selanjutnya Tim pengadaan akan melakukan pengadaan sesuai dengan kebutuhan obat yang diajukan oleh Instalasi Farmasi. Untuk pengadaan obat baru, tim pengadaan terlebih dahulu harus menerima proposal penjualan dari distributor serta surat keterangan dari dokter setempat bahwa obat tersebut memang dibutuhkan di UPT Rumah Sakit Mata Masyarakat Jawa Timur. Periode pemesanan obat dilakukan dua kali dalam satu bulan.

Sebelum melakukan pemesanan obat ke distributor, tim pengadaan terlebih dahulu melakukan negosiasi terhadap harga dan diskon yang diberikan oleh distributor. Hasil dari negosiasi antara tim pengadaan dan distributor menentukan pemesanan akan dilakukan atau tidak. Jika negosisasi telah dilakukan dan tercapai kesepakatan selanjutnya tim pengadaan akan melakukan pemesanan kepada distributor sesuai dengan permintaan dari Instalasi Farmasi. Namun, adanya diskon ini juga harus dipertimbangkan apakah lebih menguntungkan kepada rumah sakit atau tidak. Tim pengadaan akan membuat Surat Pesanan yang ditujukan kepada distributor dan setelah melakukan pemesanan tim pengadaan membuat surat perintah kerja (SPK).

Dari hasil di atas dapat disimpulkan bahwa Instalasi Farmasi UPT Rumah Sakit Mata Masyarakat Jawa Timur masih belum menggunakan metode pengadaan tertentu karena jumlah obat yang akan dilakukan pengadaan dihitung dengan menggunakan perkiraan. Namun, untuk waktu dilakukannya peengadaan berdasarkan hasil wawancara Instalasi Farmasi UPT Rumah Sakit Mata Masyarakat Jawa Timur menggunakan metode ROP (ReOrder Point) yaitu pengadaan akan dilakukan ketika stok obat sudah mencapai buffer stok.

UPT Rumah Sakit Mata Masyarakat Jawa Timur belum melakukan pengadaan sesuai 
dengan kebutuhan penggunaan obat. Hal tersebut dikarenkan perencanaan yang dilakukan juga masih belum dapat menjamin ketersediaan kebutuhan obat di Instalasi Farmasi.

Pemilihan distributor dipilih oleh tim pegadaan berasarkan proposal yang telah dibuat oleh distributor sesuai dengan mutu obat dan harga yang diberikan sehingga sebelum melakukan pengadaan obat terlebih dahulu dilakukan negosiasi antara tim pengadaan dan distributor untuk memperoleh harga yang sesuai. Namun untuk penentuan jumlah obat yang dilakukan, terutama untuk obat dengan diskon yang besar pengadaannya harus memperhitungkan mengenai baya penyimpanan. Sebab jika biaya penyimpanan besar maka juga akan menimbulkan kerugian bagi rumah sakit.

Periode pemesanan obat dilakukan dua kali dalam satu bulan sehingga dapat disimpulkan Instalasi Farmasi UPT Rumah Sakit Mata Masyarakat Jawa Timur menggunakan metode schedule purchasing yaitu pengadaan dilakukan dalam satu periode waktu tertentu. Penggunaan metode ini berjalan dengan cukup baik di Instalasi Farmasi.Penyimpanan Obat Setelah obat diterima di Instalasi Farmasi perlu dilakukan penyimpanan sebelum didistribusikan. Dari hasil wawancara, diketahui bahwa penyimpanan obat di Instalasi Farmasi UPT Rumah Sakit Mata Masyarakat Jawa Timur dibagi sesuai dengan karakteristik perbekalan farmasi yaitu obat, bahan habis pakai, alat habis pakai, bahan kimia, cairan, perbekalan farmasi laboratorium, dan optik. Penatalaksanaan obat dalam lemari penyimpanan berdasarkan huruf depan dari nama obat. Untuk persediaan LASA (Look Alike Sound Alike) disimpan di tempat yang sama seperti obat lainnya namun pada pelabelan dalam rak penyimpanan penulisannya menggunakan tinta yang berbeda.

Untuk obat jenis Psikotropika, Instalasi Farmasi tidak melakukan penyimpanan sehingga dalam gudang penyimpanan hanya terdapat tempat penyimpanannya saja. Hal tersebut dikarenakan obat Psikotropika sangat jarang digunakan di UPT Rumah Sakit Mata Masyarakat Jawa Timur.

Metode penyimpanan obat di Instalasi Farmasi UPT Rumah Sakit Mata Masyarakat Jawa Timur menggunakan FIFO (First In First Out) yaitu obat yang datang terlebih dahulu akan dikeluarkan terlebih dahulu, dan FEFO (First Expired First Out) yaitu obat yang dekat dengan masa kadaluarsa akan dikeluarkan terlebih dahulu. Khusus pada obat yang bersifat emergency selain disimpan di gudang obat, beberapa obat juga disimpan di rak yang terdapat di rawat inap, UGD, dan OK. Untuk mengetahui persediaan obat dalam gudang, setiap jenis obat memiliki kartu stok yang diletakkan di rak setiap penyimpanan obat. Kartu stok sendiri berisi data mengenai nama obat, tanggal kadaluwarsa, pemasukan, dan pengeluaran obat.

Dalam penyimpanan obat disimpan dengan rata-rata suhu di bawah $25^{\circ} \mathrm{C}$ dengan kelembaban yang harus dijaga. Selain itu, untuk beberapa obat tertentu membutuhkan tempat penyimpanan yang berbeda yaitu disimpan dalam freezer dengan suhu $<10^{\circ} \mathrm{C}$. Kelembaban di gudang penyimpanan juga haru terjaga agar obat tetap dalam kondisi mutu yang baik.

Berdasarkan hasil penelitian Kegiatan penyimpanan kebutuhan di Instalasi Farmasi UPT Rumah Sakit Mata Masyarakat Jawa Timur telah dilakukan dengan cukup baik. Hal tersebut dapat diketahui berdasarkan hasil observasi di gudang penyimpanan obat, obat yang disimpan telah diatur secara rapi dalam lemari penyimpanan disesuaikan dengan karakteristik obat. Selain itu, di Instalasi Farmasi UPT Rumah Sakit Mata Masyarakat Jawa Timur juga sudah menerapkan FIFO dan FEFO serta meletakkan perbekalan farmasi sesuai dengan urutan abjad nama perbekalan farmasi sehingga mudah dalam mencari 
perbekalan farmasi yang dibutuhkan. Adanya kartu stok obat yang diletakkan pada setiap rak obat sangat membantu dalam penerapan FIFO dan FEFO yang baik.

Penyusunan obat dilakukan berdasarkan penerimaan dan/ atau tanggal kadaluarsa nya sehingga obat yang datang terlebih dahulu dan/ atau obat yang memiliki masa kadaluarsa terdekat akan diletakkan di depan atau atas sehingga akan didistribusikan terlebih dahulu. Dalam penyusunan penempatan obat ini beberapa obat penyusunannya masih belum sesuai FIFO dan FEFO. Untuk controlling suhu dan kelembaban masih belum dilakukan setiap hari sehingga dokumen pengukuran suhu dan kelembaban menjadi kurang akurat yang disebabkan keterbatasan petugas yang menangani gudang penyimpanan.

\section{Sistem Distribusi Obat}

Berdasarkan hasil wawancara dan observasi yang dilakukan, pendistribusian obat dari Instalasi Farmasi ke Unit/ Instalasi lain diawali dengan pengajuan LPLPO ke Instalasi Farmasi oleh penanggungjawab obat di setiap unit pada hari Jumat. Selanjutnya pendistribusian obat dilakukan pada hari Senin, Penanggungjawab Obat di setiap unit yang akan mengambil obat yang sudah disiapkan oleh petugas di gudang obat. Isi dari LPLPO adalah nama obat, sisa persediaan obat di unit, serta permintaan obat setiap unit.

Metode yang digunakan dalam pendistribusian obat Instalasi Farmasi UPT Rumah Sakit Mata Masyarakat Jawa Timur adalah metode sentralisasi yaitu semua pendistribusian obat ke unit pelayanan atau instalasi terpusat pada gudang logistik. Sedangkan proses distribusi menggunakan sitem persediaan di ruang (floor stock) yaitu beberapa ruang pelayanan memiliki tempat untuk penyimpanan obat sendiri berisi obat emergency yang dapat digunakan dalam penanganan pasien gawat darurat. Monitoring terhadap sistem tersebut yakni dengan dilakukannya kunjungan setiap tiga bulan sekali secara periodik oleh petugas farmasi.

Selain itu sistem resep perorangan juga digunakan untuk menangani pasien rawat jalan sesuai dengan resep yang ditulis oleh dokter. Resep perorangan dapat ditebus di Apotek milik UPT Rumah Sakit Mata Masyarakat jawa Timur dan merupakan salah satu fasilitas pelayanan UPT Rumah Sakit Mata Masyarakat Jawa Timur.

Berdasarkan hasil observasi ditemukan adanya ketidaksesuaian antara permintaan yang tertulis dalam LPLPO dan pemberian yang dilakukan oleh Instalasi Farmasi. Ketidakesuaian ini diebabkan karena ketidaktersediaan obat yang diminta, atau petugas gudang merasa permintaan obat terlalu banyak. Apabila terjadi kekosongan stok obat, maka pihak Instalasi Farmasi akan melakukan komunikasi dengan dokter apakah obat tersebut bisa diganti dengan obat dengan jenis terapi yang sama. Jika obat tersebut tidak dapat diganti maka Instalasi Farmasi akan segera melakukan pengadaaan untuk obat tersebut. Pengadaan obat disarankan tetap dipesan pada distributor, kecuali distributor tidak dapat melayani pembelian secara mendadak maka akan dilakukan pembelian obat di apotek luar, namun sebelumnya harus melakukan konfirmasi terlebh dahulu kepada bagian Keuangan.

\section{Sistem Pencatatan dan Pelaporan Obat}

Kegiatan penctatan dan pelaporan di Instalasi Farmasi UPT Rumah Sakit Mata Masyarakat Jawa Timur menggunakan sistem manual dan komputerisasi. Kegiatan pencatatan dan pelaporannya antara lain adalah:

1. Pencatatan persediaan

Persediaan obat di Instalasi Farmasi UPT Rumah Sakit Mata Masyarakat Jawa Timur dicatat dengan menggunakan kartu stok obat yang diletakkan di atas rak setiap obat. 
Pengisian kartu stok obat dilakukan setiap kali terjadi penerimaan dan pengeluaran obat. Penncatatan pada kartu stok terdiri dari nama obat, tanggal kadaluarsa, jumlah obat, tanggal dan jumlah obat yang keluar dan masuk. Pelaporan persediaan obat dilaporkan dalam bentuk Laporan Triwulan Persediaaan Obat.

2. Pencatatan penerimaan obat

Penerimaan obat di Instalasi Farmasi UPT Rumah Sakit Mata Masyarakat Jawa Timur dilakukan pencatatan pada buku penerimaan obat/BHP/AHP dan pada program SIMBADA (Sistem Informasi Manajemen Barang Daerah). Pencatatan pada buku penerimaan mencakup nomor urut, tanggal penerimaan, nama obat, jumlah, tanggal kadaluarsa, distributor, nomor faktur, tanggal faktur, dan total biaya pembelian. Nomor urut pada buku juga digunakan sebagai nomor urut pada faktur yang selanjutnya digunakan untuk coding pada program SIMBADA. Kelemahan dari program SIMBADA adalah persediaan obat tidak dapat terakumulasi daat berganti tahun sehingga pada awal tahun petugas akan mengalami kesulitan dalam melihat ketersediaan obat.

3. Pencatatan pengeluaran obat

Berbeda dengan penerimaan obat, pencatatan pada pengeluaran obbat dilakukan pada kartu stok obat dan SIMBADA. Untuk pencatatan pada SIMBADA yang dimaksud dengan obat keluar adalah jika obat tersebut sudah dibeli atau digunakan kepada pasien. Pengeluaran obat ini disesuaikan dengan pemekaian obat yang tertulis pada LPLPO setiap Instalasi.

4. Pencatatan barang rusak

Obat yang rusak dicatat dalam berita acara barang rusak yang meliputi jenis dan jumlah obat yang dilakukan setiap 3 bulan sekali.

Pelaksanaan pencatatan penerimaan obat dilakukan dengan melihat faktur yang sudah ada dan terkumpul di
Instalasi Farmasi. Untuk pencatatan obat yang keluar dilakukan dengan melihat LPLPO yang tellah terkumpul pada hari Jumat.

Berdasarkan hasil yang telah didapatkan baik sistem manual dan komputerisai petugas harus melakukan input data sesuai dengan keadaan yang sebenarnya agar mendapatkan hasil yang lebih akurat. Terdapat beberapa kemungkinan kesalahan yang terjadi selama proses pencatatan diantaranya tidak menuliskan jumlah obat yang telah dikeluarkan/ didistribusikan dan juga kesalahan ketik terutama saat mengetik angka (Muzakkin, 2008).

Waktu dilakukannya pencatatan masih belum dilakukan setiap hari, terutama untuk pencatatan obat yang masuk. Sedangkan obat yang keluar pencatatan dilakukan setiap minggu, namun terkadang pencatatannya juga masih belum dilakukan secara rutin mengingat kesibukan dari petugas. Seharusnya, pencatatn dan pelaporan mengenai obat yang masuk dan keluar dapat dilakukan setiap hari untuk mengetahui jumlah persediaan obat.

Untuk memudahkan kegiatan ini dibutuhkan sistem informasi yang terintgrasi dimana dari setiap unit pelayanan dapat melakukan input data mengenai pengeluaran per hari dari unit tersebut ke komputer yang telah terhubung dengan gudang penyimpnan. Sedangkan pencatatan mengenai pemasukan obat juga dilakukan setiap hari oleh petugas. Dengan demikin, komputer dapat melakukan rekapitulasi mengenai persedian obat sehingga data persediaan obat dapat dikses secara real time.

\section{SIMPULAN}

Perencanaan di Instalasi Farmasi UPT Rumah Sakit Mata Masyarakat Jawa Timur masih kurang efektif sebab belum menggunakan metode tertentu untuk penentuan jumlah obat yang akan dilakukan pemesanan, namun untuk waktu 
dilkukan pemesanan menggunkan metode ROP. Proses pengadaan di Instalasi Farmasi UPT Rumah Sakit Mata Masyarakat Jawa Timur masih belum menggunakan metode dalam melakukan pengadaan. Namun untuk periode pengadaan menggunakan metode schedule purchasing yaitu pengadaan dilakukan dalam satu periode waktu tertentu. Metode penyimpanan obat di Instalasi Farmasi UPT Rumah Sakit Mata Masyarakat Jawa Timur sudah berjalan dengan baik menggunakan metode FIFO (First In First Out) dan FEFO (First Expired First Out). Pendistribusian obat Instalasi Farmasi UPT Rumah Sakit Mata Masyarakat Jawa Timur adalah metode desentralisasi. Sedangkan proses distribusi menggunakan sitem persediaan di ruang (floor stock) dan sistem resep perorangan. Dalam pelaksanaannya, masih terjadi ketidaksesuaian antara permintaan dan pemberian yang dilakukan oleh Instalasi Farmasi. Kegiatan pencatatan dan pelaporan di Instalasi Farmasi UPT Rumah Sakit Mata Masyarakat Jawa Timur menggunakan sistem manual dan komputerisasi. Kegiatan ini masih kurang efektif karena tidak dilakukan setiap hari data sehingga data persediaan obat tidak dapat diketahui secara real time.

\section{SARAN}

Berdasarkan uraian kesimpulan di atas, maka saran yang dapat diberikan adalah :

1. Dibentuknya tim khusus untuk perencanaan obat merupakan suatu kebutuhan dalam rangka meningkatkan efisiensi dan efektivitas penggunaan dana.

2. Perencanaan jumlah kebutuhan obat sebaiknya menggunakan metode trend linier karena mtode tersebut sesuai dengan kondisi persediaan di UPT RSMM Jawa Timur yang fluktuatif untuk meminimalisasi ketidaksesuaian dengan kebutuhan.

3. Pengendalian persediaan juga harus dilakukan oleh Instalasi Farmasi UPT
RSMM Jawa Timur dengan melakukan evaluasi terhadap persediaan obat periode waktu sebelumnya.

4. Melakukan koordinasi antara petugas Instalasi Farmasi dengan user/ dokter minimal setiap dua minggu sekali mengenai obat yang memiliki jumlah persediaan lebih banyak dan obat yang kehabisan stok, dengan harapan dapat terjadi pengalihan penggunaan obat sehingga bisa meningkatkan pemakaian obat dengan persediaan lebih banyak.

\section{DAFTAR PUSTAKA}

Direktorat Jenderal Bina Kefarmasian dan Alat Kesehatan. 2010. Materi Pelatihan Manajemen Kefarmasian di Instalasi Farmasi Kabupaten / Kota. Jakarta :Kementerian kesehatan RI.

Mellen, R. C dan Pudjiraharjo, W. J. 2013. Faktor Penyebab Dan Kerugian Akibat Stockout Dan Stagnant Obat Di Unit Logistik RSU Haji Surabaya. Jurnal Administrasi Kesehatan Indonesia, 1(1). Tersesia di: < http://journal. unair.ac.id/download-fullpapers10.\%20Renie\%20

Cuyno_JAKIv1n1.pdf> [diakses tanggal 27 April 2016].

Muzakkin, M. 2008. Analisis Kerugian yang Ditangung oleh RSUD Dr. Soetomo Surabaya sebagai Akibat Dari Stagnanat dan Stockout Obat (Studi Kasus di Unit Logistik Medik Instalasi Farmasi). Skripsi. Surabaya: Universitas Airlangga.

Profil Rumah Sakit Mata Masyarakat Jawa Timur. Surabaya: Rumah Sakit Mata Masyarakat Jawa Timur.

Pudjiharjo, W. J. 2015. Materi Slide Kuliah; Manajemen Logistik. Program Studi Administrasi dan Kebijakan Kesehatan Universitas Airlangga. Surabaya. 
USAID | DELIVERY PROJECT, Task Order 1. 2011. The Logistics Handbook: A Practical Guide for the Supply Chain Managment of Health Commodities. Arlington Va: USAID | DELIVERY PROJECT, Task Order 1. 